\title{
Da Revista do Departamento de Psicologia
}

À Fractal: Revista de Psicologia

\section{Eduardo Passos ${ }^{1}$}

A Revista do Departamento de Psicologia - UFF nasce em 1989. Já se vão quase 20 anos de produção. Era outro tempo da universidade brasileira. Eram outras expectativas no que se refere à produção acadêmica e ao ambiente universitário. Naquele ANO1 - No. 1 podíamos ler textos de Cristina Rauter, Regina Benevides, Ângela Fernandes, Denise Jabour, Luís Antônio Baptista e Lilia

${ }^{1}$ Professor do Departamento de Psicologia da Universidade Federal Fluminense. Endereço: Campus do Gragoatá, s/ nº bloco O, $2^{\circ}$ Andar, Sala 218, Gragoatá, CEP: 24210-350 - Niterói - RJ - Brasil. Eduardo Passos é membro do Conselho Editorial da Revista desde o ano de 1991.

E-mail: gsi@vm.uff.br. 
Lobo, todos professores da UFF que faziam daquele espaço editorial uma ágora para o debate de temas que desde sempre nos mobilizaram: as práticas psicológicas no campo da justiça penal, os grupos e instituições, a formação de professores e a escola, as ecologias, os processo cognitivos, psicologia e história. Na capa, uma coluna grega tomando toda a cena, sustentando algo. Não se podia mesmo supor, naquele momento, quantas mudanças viveríamos, quantas transformações experimentaríamos no sentido da nossa produção e no modo de ocuparmos os espaços universitários.

Hoje estamos rebatizando a revista, fazendo jus ao movimento da mudança, afirmando-o, sem abrirmos mão do que nos moveu, do que foi princípio disparador de nossas ações: a transdisciplinaridade, a inseparabilidade entre clínica e política, entre produção de saúde e produção de subjetividade, a aposta em outras políticas cognitivas, a defesa do comum e do público. Mudamos e repetimos a um só tempo, eis o paradoxo que nos orienta na nomeação da revista. Vamos designar doravante este periódico de Fractal. Por que este outro nome? Há aqui uma aposta.

A noção de fractal é um neologismo criado a partir das pesquisas de Benoit Mandelbrot, geômetra que na década de 70 dedica-se a pensar uma dimensão entre a superfície e o volume, isto é, uma figura intermediária que descreve uma dimensão fragmentar (daí fractal). Mandelbrot queria dar conta do que parecia um espaço impensável, do que escapava das geometrias do regular e do inteiro. Queria dar conta do que é intermediário, do que está no interstício: nem isso, nem aquilo. Era forçado a pensar a partir da irregularidade da costa da Bretanha, das formas das nuvens, dos cristais da neve.

Um objeto fractal é aquele cuja condição fragmentar se apresenta nas diferentes escalas com que o examinamos. Um exemplo clássico é o de um triângulo que se subdivide em quatro, e cada um desses em quatro numa operação ao infinito. A figura que resulta dessa operação qualquer que seja a sua forma atual possui nos seus diferentes níveis de análise o mesmo princípio de organização. Um programa fractal, nesse sentido, permite a criação de diferentes formas que, de fato, são apenas modulações de uma mesma unidade de formação. A repetição do fragmento realiza, então, uma gênese, uma criação. Repito e diferencio, fractalizo.

Tal fragmentação parece abolir qualquer possibilidade de unidade de uma narrativa geral, embora a operação fractalizante se estenda na forma de redes incomensuráveis, hiperextensas, hiperconectantes que, em cada nó da trama, apresenta a característica do todo. O fragmento porta o todo, contém o todo que não deixa, portanto, de ser ele também fractal.

Fazendo este elogio do fragmento, exortando a força da parcialidade, afirmando a potência do local, operando com a repetição diferenciadora, a realidade se apresenta como um sistema fractal onde cada elemento comporta o todo ou é germe dinâmico para outras totalizações. Cada fragmento da realidade traz virtualmente a totalidade da Natureza em germe. Por isso, o primado do funcionamento ou da maquinação: no fragmento encontramos um modo de operar que não nos 
permite, no entanto, determinarmos que forma advirá, que totalização emergirá. $\mathrm{O}$ que queremos dizer é que com os fragmentos da realidade pode-se operar a criação de outras Naturezas ou realidades. Uma vez destacado ou desterritorializado um fragmento de dada organização ou estrato da realidade, pode-se fazer a aposta na sua potência de germinação de novos territórios: aposta fractal.

Escolher o nome Fractal é, então, fazer nossa aposta no que a um só tempo sentimos repetir e diferir - repetir nossa alegria de estarmos ainda juntos, repetir nossa afirmação no pensamento crítico da psicologia, na transdisciplinaridade, para diferir de nós mesmos, para pensarmos, sentirmos e fazermos de outras maneiras. 